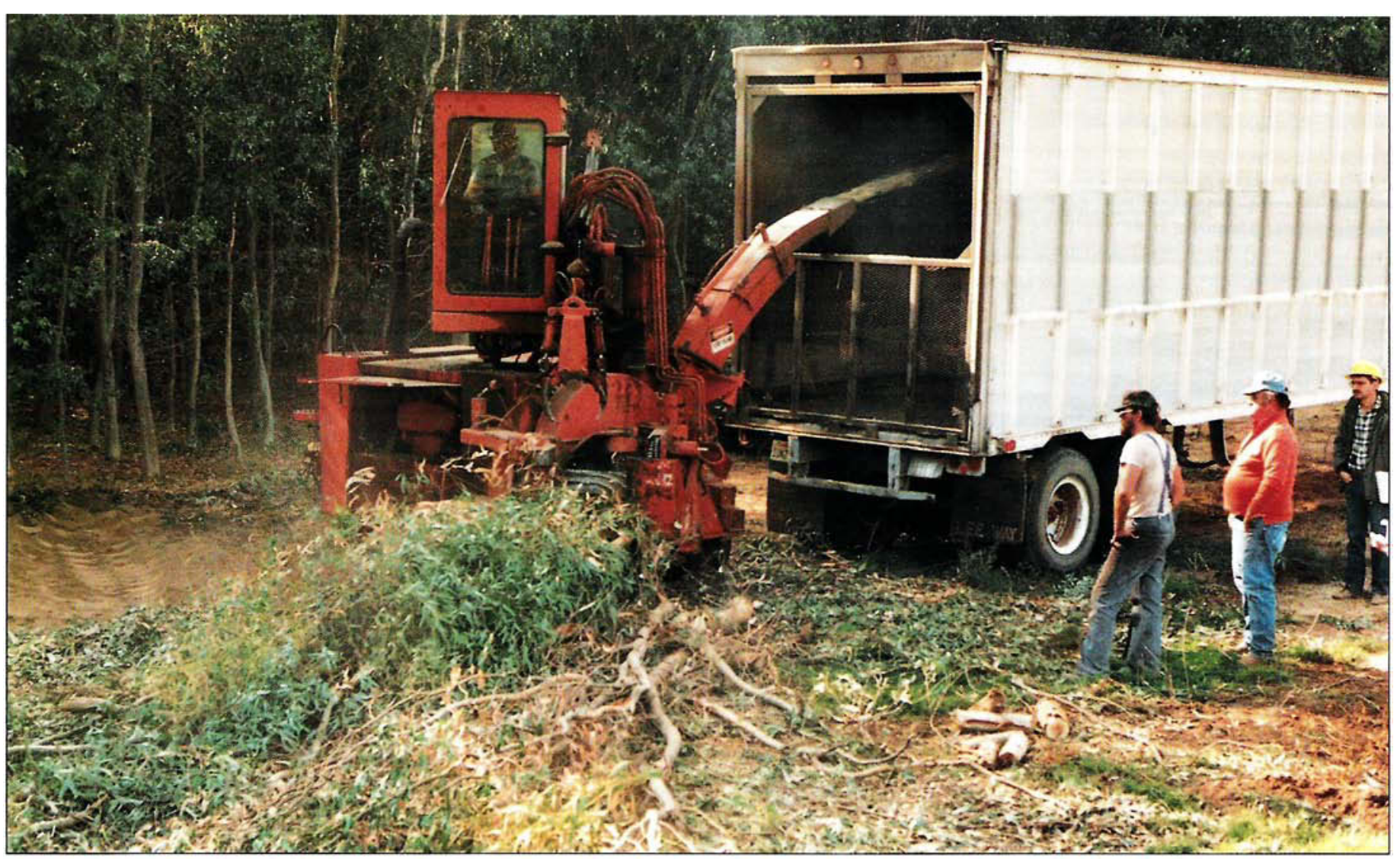

\title{
Harvesting eucalyptus for fuel chips
}

\section{Bruce R. Hartsough a Gary Nakamura}

\section{Six-year-old eucalyptus trees were harvested, chipped, and delivered to an electric power plant. Costs exceeded the value of the chips. Expenses could be reduced if big- ger trees were harvested, more acres were cut, and the stand were closer to the power plant.}

Demand for fuel chips for producing electricity is increasing in California. Generation capacity of wood-fueled plants was expected to double between 1988 and 1991, then level off. In the past, sawmill residues supplied most of the fuel needs. Plants are starting to use new sources such as forest residues, agricultural prunings, and urban wood wastes. Eucalyptus is another possible source of fuel.

The importance of harvesting costs in the economics of eucalyptus plantations is widely recognized. Several estimates for producing firewood have been made, but costs of producing other types of products are less well known. This paper describes the mechanized harvest of one plantation for fuel chips.

\section{Stand}

The 2.25-acre harvested block of trees was planted with river red gum (Eucalyptus camaldulensis) on flat ground near Orland, Tehama County, in June and July of 1983. Trees were planted at a spacing of approximately 4 by 5 feet. A sample of 542 trees measured just before harvesting gave the diameter distribution shown in table 1, and an average diameter at breast height $(\mathrm{DBH})$

TABLE 1. Diameter distribution of trees in stand

\begin{tabular}{lc}
\hline \hline DBH & Percent of total number \\
\hline inches & \\
1 & 10.5 \\
2 & 23.1 \\
3 & 30.2 \\
4 & 24.0 \\
5 & 10.7 \\
6 & 1.3 \\
7 & 0.2 \\
\hline
\end{tabular}

of 3 inches. A sample of 35 felled trees was measured for diameters along the stem, stem weight with and without bark, and top, branch, and foliage weight. Results were used to develop a local volume and biomass table (table 2).

From the viewpoint of harvesting and transportation costs, the stand had three undesirable features: small trees, little total biomass, and a relatively long haul distance between the stand and the energy facility. Nevertheless, stands with these conditions are probably common in the state.

\section{Harvesting and transportation}

The stand was harvested in late October and early November 1988. Every tree in the stand was felled and bunched with one of
TABLE 2. Average heights, green volumes, and green weights by DBH

\begin{tabular}{|c|c|c|c|c|c|c|c|c|c|}
\hline \multirow{3}{*}{$\begin{array}{l}\begin{array}{l}\text { DBH } \\
\text { class }\end{array} \\
\text { in. }\end{array}$} & \multirow{3}{*}{$\frac{\begin{array}{c}\text { Total } \\
\text { height }\end{array}}{f t}$} & \multirow{3}{*}{$\begin{array}{c}\begin{array}{c}\text { Stem } \\
\text { volume }\end{array} \\
t^{3}\end{array}$} & \multirow{3}{*}{$\begin{array}{c}\begin{array}{c}\text { Total } \\
\text { tree } \\
\text { weight }^{*}\end{array} \\
\text { lb }\end{array}$} & \multicolumn{6}{|c|}{ Weight ${ }^{*}$ and percentage } \\
\hline & & & & \multicolumn{2}{|c|}{ Stem wood } & \multicolumn{2}{|c|}{ Bark } & \multicolumn{2}{|c|}{$\begin{array}{l}\text { Top, branch, } \\
\text { and foliage }\end{array}$} \\
\hline & & & & lb & $\%$ & 16 & $\%$ & $1 b$ & $\%$ \\
\hline 2 & 25 & 0.3 & 22.3 & 11.2 & 50 & 2.7 & 12 & 8.4 & 38 \\
\hline 3 & 31 & 0.8 & 57.8 & 33.8 & 59 & 7.2 & 12 & 16.8 & 29 \\
\hline 4 & 37 & 1.7 & 113.7 & 73.8 & 65 & 14.2 & 12 & 25.7 & 23 \\
\hline 5 & 42 & 2.9 & 192.2 & 135.3 & 70 & 24.1 & 13 & 32.8 & 17 \\
\hline 6 & 47 & 4.5 & 295.1 & 222.1 & 75 & 37.2 & 13 & 35.8 & 12 \\
\hline
\end{tabular}

"Total tree, stem wood (to a 2" diameter), and bark weights (lb) were determined from regression analysis; top, branch and foliage weight by difference (total - wood - bark). 
two shear-equipped machines, a Mor-Bell Logger and a Melroe Bobcat 1080-C. Later, a Clark F666 rubber-tired skidder equipped with an Esco grapple delivered the bunches an average of 500 feet to a Morbark Super Beever chipper. The chipper blew the whole-tree chips (including bark, branches and foliage) into a setout van, and a single truck tractor shuttled vans 50 miles between the plantation and the Signal Shasta Energy Company electric power plant in Anderson, Shasta County. The harvesting equipment was normally operated on forest lands east of Red Bluff, and was transported a considerable distance to this study site.

Although the feller/bunchers and chipper were capable of handling much larger trees (10 to 11 inches DBH), smaller equipment producing at a slower rate is not likely to result in a lower harvesting cost, because the number of machine operators and, consequently, hourly labor costs are fixed.

Time-motion studies were taken of the felling and bunching, skidding, chipping, and trucking activities. Data from these production studies and estimates of longterm utilization (the ratio of productive time to scheduled time) were combined to yield expected production rates. For economical operation, a harvesting system should be well-balanced: that is, equipment for each of the stump-to-truck activities should be capable of producing at about the same rate. Since the observed system was not balanced, projections were also made for a slightly different mix of equipment. Costs were constructed for the stump-to-truck activities, based on replacement costs of the equipment. A typical hourly contract cost was assumed for trucking. Move-in costs for the observed system were based on actual move-in times and typical hourly costs for transportation and fixed costs for the idle equipment. Data on load weights and moisture contents of the chips were provided by Pacific Wood Fuels Company.

\section{Results}

A total of 84 bone-dry tons (BDT) of fuel chips was harvested. The average tree weighed an estimated 46 dry pounds. The stand was felled in a single day, while chipping required 3 days of operation. Production rates for the felling, skidding, and chipping equipment (table 3 ) assume a utilization (productive time/scheduled time) of $75 \%$ for each piece of equipment.

The production rate for the Bobcat feller/ buncher was not representative, because the operator had little experience. The tricycle undercarriage of the Mor-Bell appeared to cause less damage to stumps than did the skid-steer Bobcat. This could have implications for sprouting.

Chip load weights averaged 21.8 green tons at $44.8 \%$ moisture content (green ba- sis), or 12 BDT. Observed round-trip hauling times averaged 200 minutes.

Considerable time was spent moving equipment to and from the harvest site. Reported times and estimated costs for the various pieces of equipment are detailed in table 4 to provide an idea of their magnitude. Costs for other sites would be different.

Cost and productivity assumptions on a scheduled hour ( $\mathrm{SH}$ ) basis for the observed system, and resulting costs per bone-dry ton are shown in table 5 .

In this study, the fixed move-in costs outweighed all the other costs combined. Although move-in costs vary widely because of differences in travel distance and amount of material harvested, they cannot be ignored.

Hauling costs depend on distance, but the two are not directly proportional because

TABLE 3. Observed production rates

\begin{tabular}{lc}
\hline \hline Machine & Trees/scheduled hour \\
\hline Clark Bobcat Feller/Buncher & 123 \\
Mor-Bell Feller/Buncher & 232 \\
Clark666 Skidder & 333 \\
Morbark Super Beever Chipper & 195 \\
\hline
\end{tabular}

\begin{tabular}{lcc}
\multicolumn{3}{c}{ TABLE 4. Move-in data } \\
\hline \hline Machine & Move-in time & Move-in cost \\
\hline & $h r$ & $\$$ \\
Feller/bunchers & 12.5 & 862 \\
Skidder & 20.0 & 1,282 \\
Chipper & 15.0 & 462 \\
Chip van & 14.0 & $\underline{630}$ \\
$\quad$ TOTAL & & 3,236 \\
\hline
\end{tabular}

TABLE 5. Costs and productivities for the observed system

\begin{tabular}{|c|c|c|c|}
\hline Operation & Hourly cost & Productivity & Cost \\
\hline & $\$ / S H$ & $B D T / S H$ & $\$ / B D T$ \\
\hline $\begin{array}{l}\text { Felling } \\
\text { Skidding } \\
\text { Chipping } \\
\text { Stump-to-truc }\end{array}$ & $\begin{array}{r}65.79 \\
40.96 \\
34.48 \\
\end{array}$ & $\begin{array}{l}8.17 \\
4.48^{*} \\
4.48\end{array}$ & $\begin{array}{l}8.05 \\
9.13 \\
7.69 \\
25 .\end{array}$ \\
\hline Hauling & 45.00 & 3.60 & 12.50 \\
\hline Move-in ${ }^{0}$ & & & 38.52 \\
\hline TOTAL & & & 76. \\
\hline
\end{tabular}

NOTE: $\mathrm{SH}=$ scheduled hour. $\mathrm{BDT}=$ bone-dry ton. * Limited to the maximum rate for the chipper.

${ }^{\circ}$ Cost per ton $=\$ 3,236$ total cost $\div 84$ BDT.

TABLE 6. Costs and productivitles for a modified system

\begin{tabular}{lccc}
\hline \hline Operation & Hourly cost & Productivity & Cost \\
\hline & $\$ / S H$ & $B D T / S H$ & $\$ / B D T$ \\
Felling & 32.99 & $4.48^{*}$ & 7.36 \\
Skidding & 36.80 & $4.48^{*}$ & 8.21 \\
Chipping & 34.48 & 4.48 & $\frac{7.69}{23 .}$ \\
Stump-to-truck & & & \\
\hline
\end{tabular}

* Limited to the maximum rate for the chipper. trucks require a fixed time per trip to load and unload.

Selection of the mix of equipment is important. The combination of one Mor-Bell, a smaller skidder (such as a Clark 665), and the observed chipper would give a reasonably balanced system. With this modified configuration, the stump-to-truck costs would be reduced by about $5 \%$ (table 6 ). A slightly larger chipper would further reduce costs.

\section{Conclusion}

At current prices (about $\$ 40$ maximum per BDT delivered to an energy plant), producing fuel chips is not economical under the conditions of this study. Several factors, including small tree size, small acreage, and long haul distance, contributed to the high costs.

Many studies of forest harvesting show that stump-to-truck production rates increase and harvesting costs decrease as tree size increases, because fewer pieces must be handled per unit weight. In this stand, biomass almost doubled with each inch increase in DBH (table 2). The proportion of wood increased with increasing diameter, an important consideration for those producing pulp chips where only debarked wood is used. On the average, the trees were very small, due to the close planting, management regime, and short rotation. Optimal tree size depends on many factors in addition to harvesting costs, but it is likely that trees should be grown larger than those observed in this study to optimize economic returns. We are planning harvest trials with bigger trees.

The excessive move-in costs per BDT were incurred because of the long move-in times and the relatively small amount of material harvested. They can be reduced if (1) wood harvesting contractors become established in the vicinity of agricultural plantations and (2) more wood is removed during each harvest entry. Thus, planting a greater area in fewer age classes would be desirable on a fixed acreage, if a grower intended to produce fuel chips.

Bruce R. Hartsough is Assistant Professor, Department of Agricultural Engineering, University of California, Davis; and Gary Nakamura is Area Forestry Specialist, UC Cooperative Extension, Shasta County.

The authors thankFeng-Hua Guo, Julio Happ, and Kevin Kroneberger, Graduate Research Assistants, for field assistance; Mike Bacca and Mark Biegan, Tree Improvement Specialists, Simpson Timber Company, for collecting the tree volume and biomass data; Tad Mason, Wood Fuel Supply Manager, Pacific Wood Fuels Company, and Jim Rydelius, Research and Silviculture Manager, Simpson Timber Company, for funding the project. 